\title{
THE RELATIONSHIP BETWEEN COMPULSORY CITIZENSHIP BEHAVIOR AND LEADERSHIP: A RESEARCH BY ACCOMMODATION BUSINESSES
}

\author{
DOI: 10.17261/Pressacademia.2017.708 \\ RJBM- V.4-ISS.3-2017(7)-p.303-309 \\ Semih Soran ${ }^{1}$, Harun Sesen ${ }^{2}$, Ebru Caymaz ${ }^{3}$ \\ ${ }^{1}$ Özyeğin University, Istanbul, Turkey. semih.soran@ozyegin.edu.tr \\ ${ }^{2}$ European University of Lefke, North Cyprus. harunsesen@gmail.com \\ ${ }^{3}$ Aydın University, Istanbul, Turkey. ebrucaymaz@gmail.com
}

\section{To cite this document}

Soran, S., H. Sesen and E.Caymaz, (2017). The relationship between compulsory citizenship behavior and leadership: a research by accommodation businesses. Research Journal of Business and Management (RJBM), V.4, Iss.3, p.303-309.

Permemant link to this document: $\mathrm{http}: / /$ doi.org/10.17261/Pressacademia.2017.708

Copyright: Published by PressAcademia and limited licenced re-use rights only.

\begin{abstract}
Purpose- Compulsory citizenship behaviour (CCB) is a disparate and new topic recently presented in management literature. Organizational citizenship behaviours (OCB), being expected to have positive impact on organizational success, having been transformed to CCB as a result of various administrative and social pressures may cause several negative results due to employers and organization. The basic problem of studying within this framework is to reveal the relation between compulsory citizenship behaviour (CCB) -being evolved from volunteering to obligation (Vigoda-Gadot, 2006)-and leadership styles by focusing on the negative effects of CCB within the organization. The primary objective of our research is to establish a general framework for Compulsory citizenship behaviour in accommodation businesses sector of Turkey and to present a perspective on how leadership affects compulsory citizenship behaviour. In this way, it is aimed to provide a perspective to leaders to develop solution proposals.

Methodolgy- A five-item scale is benefited in the study, which is adapted by Compulsory Citizenship Behaviour Scale (CCBS) of Gadot (2007) in order to evaluate the compulsory citizenship behaviours of the participants. Within this scope, three hypotheses are tested based on the theoretical implications of the variables in our study.

Findings- The findings acquired within the study indicate that compulsory citizenship behaviour (CCB) has a positive relation with despotic leadership while CCB has negative relations with transformative leadership and rewarding leadership. Additionally; there is a positive and significant relationship between transformative leadership and rewarding leadership while a negative relation is revealed with despotic relation. There is a negative relationship found between despotic leadership and rewarding leadership. By evaluating the findings of regression analysis in general; it is understood that compulsory citizenship behaviour (CCB) is quite effective to explain despotic leadership, a style of leadership that is often described as negative by employees. The environment in which CCB is developed can be achieved more easily via this leadership style. Besides; though it has negative effect on rewarding leadership style, the mentioned effect is limited. In this context; CCB is suggested to have significant effect on leading styles.

Conclusion- By analysing the findings; despotic leadership has a significant impact on CCB. In the context of the study; while the negative impact of transformative leadership on CCB is detected, it is surprising that the same negative impact of rewarding leading style is limited on $\mathrm{CCB}$.
\end{abstract}

Keywords: Compulsory citizenship behaviour, citizenship behaviour, leadership styles. JEL Codes: M10, M12, M19

\section{INTRODUCTION}

Organizational citizenship behaviour (OCB) topic has been studied for years within management and organization literature. Hundreds of research held relating the issue have revealed that mentioned behaviours can produce beneficial results for 
the organization without any additional cost and the situation has caused the interest about the topic being increased much more each day. Organizational citizenship behaviour (OCB) suggested to include the positive behaviours such as volunteering, altruism, loyalty and helping (Organ, 1988), is taken into account as an important subject to increase the organizational performance, effectiveness and productivity (Podsakoff and others., 2000; Turnipseed and Murkison, 1996).

But the perspective developed for organizational citizenship behaviour (OCB) over the years has not considered the deviations sufficiently and $O C B$ has ignored the other side of medallion. Whereas several researches reveal that the organizational citizenship behaviours (OCB) done voluntarily within the organization may be used as a pressure tool in time by some stronger people (boss or colleagues) even it may become a part of the mission by deviating from the basics of volunteering (Bolino and others., 2004; Vigoda-Gadot, 2007).

The basic problem of studying within this framework is to reveal the relation between compulsory citizenship behaviour (CCB) -being evolved from volunteering to obligation (Vigoda-Gadot, 2006)-and leadership styles by focusing on the negative effects of $\mathrm{CCB}$ within the organization.

The research is designed to be composed of four parts. In the first part, literature review of OCB and leadership, in the second part data and methodology, in the third part the findings and in the final section, conclusions were included.

\section{LITERATURE REVIEW}

\subsection{From Organizational Citizenship to Compulsory Citizenship}

Organizational citizenship behaviour (OCB) is first studied by Smith, Organ and Near (1983). By this study; OCB concept is stated as "exactly based on volunteering, helping the individuals due to organization's interests and supporting the organization". Organ (1988) defines OCB in another study as "the behaviours done by individuals voluntarily also behaviours ignored for the promotions being beyond definition".

Organizational citizenship behaviour (OCB) is named by various forms within the literature such as "Good soldier syndrome" (Organ, 1988; Turnipseed and Murkison, 1996), "Extra-role behaviours" (Van Dyne and Lepine, 1998), "Contextual performance" (Motowidlo and Van Scotter, 1994) or "Prosocial organizational behaviour" (Brief and Motowidlo, 1986). In this case OCB includes positive behaviours such as being sensitive while reacting the mistakes, solving the matters by discussing, accomplishing the business just in time and supporting the colleagues (Kidwell and the others 1997; Podsakoff and the others, 2000).

Many dimensions belonged to organizational citizenship behaviour $(O C B)$ are observed to be researching topics while studying the literature. It is stated by Podsakoff (2000) that nearly 30 dimensions of OCB are studied. One of the most important studies herein; Organ (1988) defines the 5-dimensional structure of organizational citizenship behaviour (OCB) as kindness, altruistism, being conscientious, gentility and civil virtue. Besides the 2-dimensional study by Williams and Anderson (1991) is benefited in common.

Gadot (2006) debates the concept of compulsory citizenship behaviour (CCB) by questioning the border between the success of organization and feeling obliged to work in order to achieve organizational success for employees. Gadot, by arguing about the compulsory citizenship behaviour (CCB) due to the compulsive chief, states that compulsive behaviours can affect organizatinal behaviours in negative manner such as work stress or burnout. Gadot (2006), stating that behaviours occurred by force cannot be defined as organizational citizenship behaviour (OCB) because it is based on the individual's volunteering preference, mentions the concept of compulsory citizenship behaviour (CCB).

Gadot (2006: 85) defines the compulsory citizenship behaviour (CCB) as "Doing some behaviours being on the basis of volunteerism coercible, due to forcing; as a result of the pressure within organization,". In other words; these behaviours can be called as CCB when the individual have to display prosocial behaviours in the business environment. For the formation of compulsory citizenship behaviour (CCB); obedience of employees are required to environmental conditions besides they have to show positive behaviours beyond their role out of duty (Gadot, 2007). Certainly; every kind of behaviours beyond role are not to be evaluated as compulsory citizenship behaviour (CCB). If an employee accepts, someone else's duty while his/her absence voluntarily or helps him/her for any matter willingly; this type of behaviour cannot be described as CCB. However; whether an employee has to display that kind of behaviours due to the pressure via boss / the chief or if he/she is obliged to do so, compulsory citizenship behaviour (CCB) can be mentioned. As an example, if boss or the chief forces any employee to work on his/her own also request them to train a new colleague at the same time that kind of behaviour can be defined as CCB. As a result; the employee has to set balance between his/her own duty's necessities and the request by the chief.

An aggressive manager or coercive persuasion behaviour within the literature are admitted as the basic premise of compulsory citizenship behaviour (CCB) (Gadot, 2006). According to Tepper (2000: 178) aggressive manager behaviour is defined as "the manager's hostile attitude by verbal or varied behaviours without physical contact". That kind of behaviours 
are observed to be displayed to subordinates for the managers who are anxious about losing their jobs and cannot dare to face negative consequences (Tepper and the others, 2004). Encouraging the organizational citizenship behaviour (OCB) within the organization in order to create a positive working environment and obtain high productivity is quite important. However; expressing this situation intensively and forcing the employees makes organizational citizenship behaviour (OCB) to be transformed into compulsory citizenship behaviour (CCB).

By his research relating the outputs of CCB; Gadot (2007) studies the relationship between compulsory citizenship behaviour ( $C C B$ ) of several teachers working in Israel and various organizational outputs such as job stress and their satisfaction. Most of the participants stated that they feel enormous pressure to display CCB. The findings of Gadot indicate that compulsory citizenship behaviour (CCB) may be more common within business environment than they are suggested. Gadot (2007) finds out that compulsory citizenship behaviour (CCB) is positively correlated with the variables such as job stress, organizational policy, intention to leave work and burnout while CCB has negative correlation with innovation, job satisfaction and business performance. In this framework; the aim of the study is contributing the developing literature of the field by studying the dynamics of compulsory citizenship behaviour (CCB) within another culture and sector.

\subsection{Leadership and Compulsory Citizenship Relation}

Even if leadership studies analyse mostly the relations between manager and subordinates, the leaders are not managers as well. According to Akgemici (1997) leadership can be defined as leading and managing specific people or groups to achieve their goals. Morden (1997) concludes that leadership is doing business via others. Leadership is a dynamic process including the influencing of individuals in order to contribute the others and groups to achieve their duties. The mentioned influencing will be absolutely justified and reasonably accepted by those who react positively to the leadership process.

Observing various leadership styles within the literature is possible. Leadership styles are the main reasons for the individual supporting to design their own attitudes (Larson and Kendrith, 1974). Researchers are in the exertion of classifying in the context of leadership theories. One of the most observed classifying is being held due to group's size, their situation and their understanding and behaviours. In this study; especially transformative, despotic (autocratic) and rewarding leadership styles are studied.

\subsubsection{Transformative Leadership}

It is one of the most effective leadership styles. Transformative leadership style is observed to be closely related with individual's development in the cause of analysing the literature (Çelik, 1999). Transformative leaders create a relationship that can transform employees into leaders and the leaders into ethical value followers through their mutual understanding and appropriate environment (Sosik ve Shelley, 1997). The transformative leaders try to teach their followers the importance of taking their interests on the second plan in the name of the interests of the group or business. By enhancing the self-confidence, competence and effectiveness of followers, they have a positive impact on self-promotion, motivation and job performance (Jung and Avolio, 1999).

\subsubsection{Despotic Leadership}

Despotic leadership within the literature is identified with an oppressive and aggressive attitude. Subordinates cannot do anything without an exact order of their despotic leader. The leader, on his own, is the only decision maker (Altun, 2000). Despite of being an old style of leadership, it still maintains its validity today. Both the management and the decisionmaking authorities are solely belonged to the leader.

According to Bakan and Büyükbeşe (2010) it has utilities such as meeting the expectations of the group members within the autocratic and bureaucratic societies additionally allowing the leader to make more efficient and faster decisions by providing them an independent movement area owing to having faith and confidence; while despotic leadership may cause the leader to behave extremely selfish also it may result a decline in the motivation, job satisfaction and creativity of group members by not allowing them to express themselves. Despotic leadership often leads to repressed anger and hostilities which is reducing performance and job satisfaction (Baumgartel, 1957).

\subsubsection{Rewarding Leadership}

Transactional (rewarding, interacting) leadership is defined as leaders who motivate their employees always on reward basis (Burns, 1978). The typical characteristic of rewarding leaders is setting goals, clarifying the relationship between reward and performance, and providing constructive feedback to employees (Jung ve Avolio, 1999).

Though the type of leadership subject is often discussed within the literature; the most common view admitted by management scientists states that the leadership type is detected due to organizational environment, the structure of management and the duties, conditions and characteristics of the leader. In the recent studies, leadership styles have been associated with many different variables. Chapman (1975) studies the styles of women and men leaders, Delbecq (1964) 
analyzes managerial leading types, Helmich and Paul (1975) examine leadership styles and the needs of the leaders, Rotemberg and Saloner (1993) study on leadership and incentives.

Several organizational citizenship behaviour (OCB) studies figure out findings about the relation between leader's attitudes and OCB factors. The leadership styles are revealed to help setting stronger reciprocal relations in the business within the mentioned studies (Graham, 1990). Podsakoff and the others (2000) have a study analyzing the relationship between organizational citizenship behaviour (OCB) and leading styles. According to the results; there is a negative relationship found between directing leadership and OCB also a positive one between supporting leadership style and OCB (Euwema and the others, 2007).

Although the relation between organizational citizenship behaviour (OCB) and leading styles are studied; any study has not been met about the relationship between leadership styles and compulsory citizenship behaviour (CCB). The aim of this study is studying the relations between leadership styles and compulsory citizenship behaviour (CCB) to meet the mentioned need within the literature.

Compulsory citizenship behaviour is a quite new topic within both national and international literature. Thus; the amount of studies about the subject is reasonably limited. The only applied research relating the topic is held by Gadot (2007) on a group of teachers in Israel; a positive correlation is revealed within the study between compulsory citizenship behaviour (CCB) and job stress, organizational politics, intent to leave work, negligent behavior and burnout furthermore the CCB concept is found to have negative correlation with innovation, job satisfaction, group-level, OCB and duty performance. In this framework; several variables as leading styles, that Gadot (2007) has not studied their relations with CCB, are analyzed in this research in order to reveal the relations between leadership styles and compulsory citizenship behaviour (CCB). The hypothesis formed in this framework are as follows:

Hypothesis 1: There is a positive relationship between despotic leadership and CCB.

Hypothesis 2: There is a negative relationship between transformative leadership and CCB.

Hypothesis 3: There is a negative relationship between rewarding leadership and CCB.

\section{DATA AND METHODOLOGY}

An amount of 635 working people from various accommodation businesses are participated in the study. The participants herein are between 18 and 63 ages (Average=26.96 and Standard Deviation=7.73); their duration spent in the firm is between 1 and 33 years (Average $=4.70$ and Standard Deviation=5.65). 36.2\% of the participants are women and $63.7 \%$ are men. Data obtained from those 635 questionnaires were analysed through the SPSS statistical packet program and three proposed relations were tested through regression analyses

A five-item scale is benefited in the study, which is adapted by Compulsory Citizenship Behaviour Scale (CCBS) of Gadot (2007) in order to evaluate the compulsory citizenship behaviours of the participants. Marking of the participants about what extent they agree relating the expressions mentioned in the forms on Five-point Likert scale (1- I never agree; 5- I completely agree) is requested. Reliability coefficient of the scale (Cronbach alpha) is measured as .94 within the study.

\section{FINDINGS AND DISCUSSIONS}

The correlation findings acquired within the study indicate that compulsory citizenship behaviour (CCB) has a positive relation with despotic leadership ( $r=.54, p>.01)$ while CCB has negative relations with transformative leadership ( $r=-.19$, $p>.01)$ and rewarding leadership $(r=-.12, p>.01)$. Additionally; there is a positive and significant relationship $(r=.59, p>.01)$ between transformative leadership and rewarding leadership while a negative relation $(r=-.23, p>.01)$ is revealed with despotic relation. There is a negative relationship $(r=-.19, p>01)$ found between despotic leadership and rewarding leadership. The results of the analysis are illustrated in Table 1.

Table 1:Averages, Standard Deviation and Correlations

\begin{tabular}{|l|c|c|c|c|c|c|}
\hline Variables & Average & Std. Dev. & $\mathbf{1}$ & $\mathbf{2}$ & $\mathbf{3}$ & $\mathbf{4}$ \\
\hline 1.Compulsory citizenship & 2,88 & 0,89 & $(0,91)$ & & & \\
\hline 2.Transformative leadership & 3,76 & 0,79 & $-0,19 * *$ & $(0,89)$ & & \\
\hline 3. Rewarding leadership & 3,68 & 0,90 & $-0,12^{* *}$ & $0,59 * *$ & $(0,88)$ & \\
\hline 4. Despotic leadership & 2,48 & 0,97 & $0,54 * *$ & $-0,23 * *$ & $-0,19 * *$ & $(0,90)$ \\
\hline
\end{tabular}


In order to detect the effect of CCB on dependent variables; hierarchical regression analysis is held in the study. Firstly; the demographic variables such as "age" and "duration spent in the firm" are included in the study at the first stage within the regression analysis and their effects are controlled. At the second stage; the effect of CCB are examined.

Table 2: Compulsory Citizenship Behavior Regression Results

\begin{tabular}{|l|c|c|}
\hline Variables & B & $R^{2}$ \\
\hline Stage 1 & & 0,02 \\
\hline Age & $-0,09 *$ & \\
\hline Duration spent in firm & $-0,05$ & \\
\hline F & \multicolumn{2}{|c|}{$3,551^{* *}$} \\
\hline Stage 2 & \multicolumn{2}{|c|}{0,31} \\
\hline Age & $-0,07$ & \\
\hline Duration spent in firm & $-0,08$ & \\
\hline Transformative leadership & $-0,07^{*}$ & \\
\hline Rewarding leadership & 0,02 & \\
\hline Despotic leadership & $0,52^{* * *}$ & \\
\hline F & \multicolumn{2}{|c|}{$40,582^{* * *}$} \\
\hline
\end{tabular}

Hypothesis 1 tests a positive relation between $C C B$ and despotic leadership. The findings reveal that despotic leadership has a significant effect on CCB $(\beta=.52, p>.001)$. Hence; Hypothesis 1 is accepted.

Hypothesis 2 tests a negative relationship between $C C B$ and transformative leadership. According to the results obtained; transformative leadership has a negative effect on $\operatorname{CCB}(\beta=-.07, p<.10)$. Consequently; Hypothesis 2 is accepted.

Hypothesis 3 tests a negative relationship between CCB and rewarding leadership. Due to the findings; it is revealed that rewarding leadership has not a significant effect on $\operatorname{CCB}(\beta=-.07, p<.10)$. So that Hypothesis 3 is rejected.

By evaluating the findings of regression analysis in general; it is understood that despotic leadership is quite effective to explain compulsory citizenship behaviour (CCB), a style of leadership that is often described as negative by employees. The environment in which CCB is developed can be achieved more easily via this leadership style. Besides; though it has negative effect on rewarding leadership style, the mentioned effect is limited. In this context; leading styles is suggested to have significant effect on CCB.

\section{CONCLUSION}

The basic aim of the study is to reveal the relation and reciprocal interaction of compulsory citizenship behaviour (CCB) -a limited studying topic- with various leadership styles. Within the study held via reliable and valid scales detected; the single factor structure of organizational citizenship behaviour (OCB) scale and 3-factors structure of other scales are confirmed. According to the results of correlation analysis; a positive relation exists between CCB and despotic leadership besides there are negative relations between $\mathrm{CCB}$ and transformative also rewarding leadership styles. Furthermore due to the findings; positive and significant relations exist between transformative and rewarding leadership styles besides there is a negative one between transformative and despotic leading style. Additionally a negative relationship exists between despotic and rewarding leadership.

By analysing the regression findings; although it is not surprising that despotic leadership has a significant impact on CCB which is perceived as negative by employees $(\beta=.52, p>.001)$, revealing herein the explanation ability of CCB about the mentioned leading style is important. In other words; that kind of working environment -in which CCB can develop and provide itself a legitimate basis- may be obtained by that leadership style. Owing to the findings acquired; it is concluded that CCB would be met frequently in the working environment where the despotic leadership is concerned.

As it is mentioned at the beginning of the study; general acceptance within the literature is as follows: Compulsory citizenship behaviour ( $C C B$ ) has positive relations with the leadership and attitude styles perceived as negative notions further CCB has negative relationship with the leading and attitude styles which are perceived as positive. In the context of the study; while the negative impact of transformative leadership on CCB is detected, it is surprising that the same negative impact of rewarding leading style is limited on CCB. 
The study include several limitations. The most important limitation is the problem of generalization issue. Because the sample benefited within the study includes solely a certain amount of middle level managers. A research including a more expanded sample will provide better results. Further studies are to examine the limitation of rewarding leadership style effect on CCB's by benefiting an expanded sample.

\section{REFERENCES}

Akerlof, G.A. 1970, "The Market for "Lemons": Quality Uncertainty and the Market Mechanism", Quarterly Journal of Economics, vol. 84, no. 3, pp. 488-500.

Alessandri, T., Cerrato, D. \& Depperu, D. 2014, "Organizational slack, experience, and acquisition behavior across varying economic environments", Management Decision, vol. 56, no. 5, pp. 967-982.

Akgemci, T., 1997. "Liderlik prensipleri ve lider özellikleri", Konya Personel Eğitim Komutanlığı Yönetimde Verimlilik Esasları Sempozyumu, 149-162.

Altun, H. ve Çelik, A., 2000. Kriz ortamında liderlik, K.H.O. Yayınları, Ankara.

Tamsin, A., Metcalf, L., ve Benn, S. 2010. Leadership styles and CSR practice: An examination of sensemaking, Institutional Drivers and CSR Leadership: Journal of Business Ethics, Vol. 93, No. 2, 189-213

Bakan, I, Büyükmeşe, T., 2010. Liderlik türleri ve güç kaynaklarına ilişkin mevcut-gelecek durum karşılaştırması: Eğitim kurumu yöneticilerinin algılarına dayalı bir alan araştırması, KMÜ, Sosyal ve Ekonomik Araştırmalar Dergisi 12 (19): 73-84.

Bateman, T. S. ve Organ, D. W. 1983. Job satisfaction and the good soldier: the relationship between affect and employee citizenship. Academy of Management Journal, 26, 587-595.

Baumgartel, H., 1957. Leadership style as a variable in research administration. Administrative Science Quarterly, Vol. 2, No. 3, $344-360$.

Bolino, M. C., Turnley, W. H., ve Niehoff, B. P. 2004. The other side of the story: Reexamining prevailing assumptions about organizational citizenship behavior. Human Resource Management Review, 14, 229-246.

Brief, A. P. ve Motowidlo, S. J. 1986. Prosocial organizational behaviors. Academy of Management Review, 11, 710-725.

Burns, J. M. (1978), Leadership. New York: Harper \& Row.

Chapman, J. Brad, 1975, Comparison of male and female leadership styles, The Academy of Management Journal, Vol. 18, No. 3, 645-650.

Çelik, V. 1999. Eğitimsel liderlik. Ankara: Pegem Yayınları.

Delbecq, Andre' L., 1964, Managerial Leadership Styles in Problem-Solving Conferences, The Academy of Management Journal, Vol. 7, No. 4, 255-268

Euwema, M. C., Wendt, H. ve Emmerik, H., 2007. Leadership styles and group organizational citizenship behavior across cultures, Journal of Organizational Behavior, Vol. 28, No. 8, 1035-1057.

Folger, R. 1993. Justice, motivation and performance beyond role requirements. Employee Responsibilities and Rights Journal, 6, $239-248$.

Graham, J. W. 1990. Leadership, moral development, and citizenship behavior, Business Ethics Quarterly, Vol. 5, No. 1, 43-54.

Helmich, D. L., ve Paul E. E., 1975. Leadership style and leader needs, The Academy of Management Journal, Vol. 18, No. 2, $397-402$.

Hoffman, B. J., Blair, C. A., Meriac, J. P., ve Woehr, D. J. 2007. Expanding the criterion domain? A quantitative review of the OCB literature. Journal of Applied Psychology, 92, 2, 555-566.

Jung, D. I. ve Avolio, B., 1999. Effects of leadership style and followers' cultural orientation on performance in group and individual task conditions, The Academy of Management Journal, Vol. 42, No. 2, 208-218.

Kidwell, R., Mossholder, K. ve Benneth, N. 1997. Cohesiveness and organizational citizenship behavior. Journal of Management, 23, 6, 775793.

Larson, L. L., ve Kendrith M. R., 1974, Leadership style and cognitive complexity, The Academy of Management Journal, Vol. 17, No. 1, 3745 .

Morden, Tony, 1997, "Leadership as competence", Management Desicion, 35/7, 519-526.

Moorman, R. H. 1991. Relationship between organizational justice and organizational citizenship behaviors: Do fairness perceptions influence employee citizenship? Journal of Applied Psychology, 76, 845-855.

Organ, D.W. 1988. Organizational citizenship behavior: The good soldier syndrome. Lexington, England: Lexington Books.

Podsakoff, P. M., Ahearne, M. ve Mackenzie, S. B. 1997. Organizational citizenship behavior and the quantity and quality of work group performance. Journal of Applied Psychology, 82, 262-270. 
Podsakoff, P.M., Mackenzie, S.B., Paine, J.B., ve Bachrach, D.G. 2000. Organizational citizenship behaviors: A critical review of the theoretical and empirical literature and suggestions for future research. Journal of Management, 26, 3, 513-563.

Rioux, S. M. ve Penner, L. A. 2001. The causes of organizational citizenship behavior: A motivational analysis. Journal of Applied Psychology, $86,6,1306-1314$

Rotemberg, Julio J. and Garth Saloner, 1993, Leadership style and incentives. Management Science, Vol. 39, No. 11, 1299-1318.

Smith, C. A., Organ, D. ve Near, Y. 1983. Organizational citizenship behavior: Its nature and antecedents. Journal of Applied Psychology, 68, 4, 653-663.

Sosik, J. J. ve Shelley D. D., 1997. Leadership styles and Deming's behavior factors, Journal of Business and Psychology, Vol. 11, No. 4, 447462 .

Tepper, B. J. 2000. Consequences of abusive supervision. Academy of Management Journal, 43, 2, 178-190.

Tepper, B. J., Duffy, M. K., Hoobler, J., ve Ensley, M. D. 2004. Moderators of the relationships between coworkers' organizational citizenship behavior and fellow employees' attitudes. Journal of Applied Psychology, 89, 3, 455-465.

Turnipseed, D., ve Murkison, G. 1996. Organizational citizenship behavior an examination of influence the workplace. Leadership and Organizational Development Journal, 17, 42-47.

Van Dyne, L., ve Lepine, J. A. 1998. Helping and voice extra-role behaviors: Evidence of construct and predictive validity. Academy of Management Journal, 41, 108-119.

Vigoda-Gadot, E. 2006. Compulsory citizenship behavior: Theorizing some dark sides of the good soldier syndrome in organizations. Journal for the Theory of Social Behavior, 36, 1, 77-93.

Vigoda-Gadot, E. 2007. Redrawing the boundaries of OCB? An empirical examination of compulsory extra-role behavior in the workplace. Journal of Business and Psychology, 21, 3, 377-405.

Williams, L. ve Anderson, S. 1991. Job satisfaction and organizational commitment as predictors of organizational citizenship and in role behaviors. Journal of Management, 17, 601-617. 